\title{
Ege Üniversitesi Hastanesi veri tabanında kayıtlı erişkin Hodgkin dışı lenfoma olgularının epidemiyolojik özelliklerinin retrospektif olarak değerlendirilmesi
}

Retrospective evaluation of the epidemiological and overall survival characteristics of adult non-Hodgkin lymphoma cases registered to Ege University Hospital database

\begin{tabular}{|c|c|c|c|}
\hline Derya Demir ${ }^{1}$ (D) & Nazan Özsan 1 (D) & Emre Demir² (D) & Ayşenur Arslan 3 (1) \\
\hline Eren Arslan Davulcu ${ }^{3}$ (D) & Nur Akad Soyer 3 (D) & Başak Doğanavşargil ${ }^{1}$ (D) & Güray Saydam 3 (D) \\
\hline Mahmut Töbü3 (D) & Mine Hekimgil ${ }^{10}$ & & \\
\hline \multicolumn{4}{|c|}{${ }^{1}$ Ege Üniversitesi Tıp Fakültesi Tıbbi Patoloji Anabilim Dalı, İzmir, Türkiye } \\
\hline \multicolumn{4}{|c|}{${ }^{2}$ Ege Üniversitesi Tıp Fakültesi Kardiyoloji Anabilim Dalı, İzmir, Türkiye } \\
\hline \multicolumn{4}{|c|}{${ }^{3}$ Ege Üniversitesi Tıp Fakültesi Hematoloji Bilim Dalı, İzmir, Türkiye } \\
\hline
\end{tabular}

Öz

Amaç: Hodgkin dışı lenfomalar (NHL), lenfoproliferatif hastalıkların da yer aldığı heterojen bir gruptur. $\mathrm{Bu}$ çalışmada, NHL olgularının epidemiyolojik analizlerinin yapılması, global sonuçlarla karşılaştırılarak değerlendirilmesi amaçlanmıştır.

Gereç ve Yöntem: Ege Üniversitesi Kanserle Savaş Araştırma ve Uygulama Merkezi veri tabanına kayıtlı, 1992-2017 yıllarında NHL tanısı alan 4.561 erişkin olgu retrospektif olarak değerlendirilmiştir.

Bulgular: Olguların \%56,7'si erkek olup; ortalama yaş 56,77, ortanca yaş 59 idi. En sık \%38,1 diffüz büyük B-hücreli lenfoma (DBBHL) olmak üzere sırasıyla küçük lenfositik lenfoma, marjinal zon lenfoma, folliküler lenfoma (FL) izlendi. Olguların \%52,5'i nodal, \%31'i ekstranodal yerleşimden tanı aldı. Matür B-hücreli neoplazmlar yıllara göre artış gösterirken, matür T-hücreli neoplazmlarda artış saptanmadı. Sınıflandırılamayan NHL olgularının ise yıllara göre azaldığı dikkatimizi çekti. Tüm yaş gruplarında erkeklerde kadınlara göre daha fazla idi $(p=0,003)$. Olguların yaklaşık yarısı 40-64 yaş aralığındaydı. Ayrıca mantle hücreli lenfoma (MHL) hariç, diğer histolojik tiplerin en çok 40-64 yaş aralığında; MHL'nın ise en çok 65 yaş ve üstü grupta karşımıza çıktığı izlendi. Çocukluk yaş grubunda sık görülen Burkitt lenfomada ise olguların \%86,2'si 18-64 yaş aralığında idi.

Sonuç: FL, Batı Avrupa ve Kuzey Amerika'da daha sık görülürken, DBBHL Dünya'da daha yaygın görülmektedir. Bizim çalışmamızda da DBBHL en sık görülen NHL tipidir. FL ise Batı toplumları ile kıyaslandığında daha az karşımıza çıkmaktadır. Çalışmamızda NHL'ler erkeklerde kadınlara göre daha sıktır. Ayrıca yıllara göre hastalığın lokalize kalma eğiliminin arttığı ve yaş gruplarına göre de 1839 yaş aralığında daha lokalize kalma eğiliminde iken, yaş arttıkça daha yaygın hastalık tablosu oluşturduğu dikkatimizi çekmiştir. NHL'ye ait 25 yılı kapsayan çok geniş bir serinin değerlendirildiği çalışmamız, ülkemize ait epidemiyolojik verilerin belirlenebilmesi açısından önem taşımaktadır.

Anahtar Sözcükler: Hodgkin dışı lenfoma, epidemiyoloji, insidans.

Sorumlu yazar: Derya Demir

Ege Üniversitesi Tıp Fakültesi Tıbbi Patoloji Anabilim Dalı,

İzmir, Türkiye

E-posta:dr.derya.demir@gmail.com 


\section{Abstract}

Aim: Non-Hodgkin's lymphomas (NHL) are a heterogeneous group of lymphoproliferative diseases. The aim of this study was to evaluate the epidemiological analysis of NHL patients and compare them to global findings.

Materials and Methods: The data including 4.561 adult patients diagnosed as NHL, and recorded at Ege University Cancer Control and Research Center, within 1992-2017 were evaluated retrospectively.

Results: Of the patients, $56.7 \%$ was male; the mean age was 56.77 , the median age was 59 . The most common lymphoma type of $\mathrm{NHL}$ was $38.1 \%$ diffuse large B-cell lymphoma (DLBCL), followed by small lymphocytic lymphoma, marginal zone lymphoma, follicular lymphoma (FL). 52.5\% of the patients had been diagnosed within nodal, $31 \%$ extranodal localization. While mature B-cell neoplasms increased in years, mature T-cell neoplasms did not increase in years. The non-specified type of NHL decreased in years. The disease was significantly higher in males than females in all age groups $(p=0,003)$. About half of the patients were in the age range of 40-64. Except for mantle cell lymphoma, which was mostly detected in patients older than 64 years, all other types were mostly seen in the 40-64 age range $86.2 \%$ of Burkitt lymphoma patients, which is mostly diagnosed in pediatric age group, were in the 18-64 age range.

Conclusion: While FL is more common in Western Europe and North America, DLBCL is more common in the World. In our study, DLBCL is the most common NHL type, FL is less common compared to Western countries. NHL incidence is more common in males than females in our study. Also, the ratio of localized disease increase in years, and while the ratio of localized disease is more in the 18-39 age range, the disseminated disease is more detected in years of older age. In our study, we evaluated an extensive series of NHL patients diagnosed in 25 years' period, and it provides an important epidemiological data for our region of the country.

Keywords: Non-Hodgkin lymphoma, epidemiology, incidence.

\section{Giriş}

Hodgkin dişı lenfomalar (NHL); $B$ veya $\mathrm{T}$ lenfositler ya da NK hücrelerinden gelişebilen matür $B$ hücreli ve matür T/NK hücreli neoplazmlar olmak üzere iki grupta ele alınmaktadır. Matür B hücreli neoplazmlar, NHL'ler içerisinde en sık karşımıza çıkar. Pregerminal merkez, germinal merkez veya postgerminal merkez $\mathrm{B}$ hücrelerinden köken alabilir $(1,2)$. Mantle hücreli lenfoma (MHL), pre-germinal merkez B hücrelerinden gelişirken; folliküler lenfoma $(F L)$, Burkitt lenfoma $(B L)$ ve diffüz büyük $B$ hücreli lenfomanın (DBBHL), germinal merkez alt tipi gibi bazı lenfomalar germinal merkez $B$ hücrelerinden ve diffüz büyük $B$ hücreli lenfomanın, germinal merkez dışı alt tipi gibi bazı lenfomalar da post-germinal merkez B hücrelerinden gelişir (2). NHL'ler, lenf nodülü, dalak gibi lenfoid dokularda daha sık karşımıza çıkmakla birlikte; mide, barsak, deri gibi ekstranodal organlarda da sık olarak görülmektedir. NHL'ler lenfoproliferatif hastalıkları da içeren heterojen bir gruptur ve çok sayıda antiteyi içerisinde barındırır (2,3). Daha yavaş büyüyen ve az semptom oluşturan indolan lenfomalar olan $\mathrm{FL}$, marjinal zon lenfoma (MZL), lenfoplazmasitik lenfoma (LPL) yanı sıra daha hızlı büyüyen, hızlı yayılan ve şiddetli klinik semptomlara yol açan agresif lenfomalar olan DBBHL, BL, HIV ile ilişkili lenfomalar, transformasyon gösteren lenfomalar, anaplastik büyük hücreli lenfoma $(A B H L)$ ve çoğu periferal $T$ hücreli lenfomalar (PTHL) bunlar arasında sayılabilir $(1,2)$.

Bu çalışmada, Ege Üniversitesi Tıp Fakültesi (EÜTF) Hastanesi veri tabanına kayıtlı, 1992- 
2017 yıllarında NHL tanısı alan 4.561 erişkin olgunun epidemiyolojik analizlerinin yapılması, global sonuçlarla karşılaştırılarak değerlendirilmesi amaçlanmıştır.

\section{Gereç ve Yöntem}

EÜ Kanserle Savaş Araştırma ve Uygulama Merkezi (EÜKAM)'nin özel eğitimli ve sertifikalı kanser kayıt elemanları tarafından 1992-2017 yıllarında, EÜTF Hastanesinde 4.837 NHL tanısı alan hasta kaydı yapılmıştır. Çocuk hastalar (18 yaş altı) pediatri grubunda ele alınacağı için çalışmadan dışlanarak, 4.561 erişkin $\mathrm{NHL}$ hastası çalışmaya dahil edilmiştir. Bu hastalar hastanemizde tanı ve/veya tedavi almışlardır. Sınıflandırmalarda DSÖ ve SEER (Surveillance, Epidemiology, and End Results) verileri göz önüne alınarak gruplandırılmış; tümörün histolojik tipi, tanı yaşı, cinsiyet, tümör yerleşim yeri, hastalığın yaygınlığı açısından değerlendirilmiştir (1). Tümörün histolojik tipi açısından, DSÖ 2017 kitabına göre alt tiplere ayrılmıştır (1). CANREG 4 programı ile kaydedilen veriler SPSS (23) programına aktarılmıştır. İstatistiksel analizlerde Ki-kare, doğrusal modellemeler, student T-test, Mann Whitney-U, Fischer-exact test uygulanmış, p <0,05 değeri anlamlı kabul edilmiştir. Bu çalışmada, Ege Üniversitesi Tıbbi Araştırmalar Etik Kurulundan onay alınmıştır.

\section{Bulgular}

1992-2017 yıllarında EÜTF Hastanesi veri tabanında kayıtlı 117.139 hastanın, 6.130'u lenfoma tanısı almıştır. Lenfoma tanısı alan olgular, hastanemiz veri tabanında kayıtlı tüm olguların yaklaşık \%5'ini oluşturmaktadır. NHL ise lenfoma tanısı alan olguların yaklaşık \%79'unu ve tüm malignitelerin ise $\% 4,1$ 'ini oluşturmaktadır.

Matür B ve T/NK Hücreli Neoplazmlarda Epidemiyolojik ve Histopatolojik Özellikler

Matür B ve T/NK hücreli neoplazm tanısı almış olan 4.561 olgunun 2.586'sı $(\% 56,7)$ erkek, 1.975 'i $(\% 43,3)$ kadın olup; ortalama yaş 56,77 $( \pm 15,60)$, ortanca yaş 59 (aralık:18-100) olarak bulundu. Histolojik tiplerine baktığımızda, en sık $\% 38,1$ DBBHL olmak üzere sırasıyla $\% 16,1$
KLL/SLL, \%7,2 MZL, \%6,9 FL olmak üzere sıralandığı dikkatimizi çekti (Şekil-1). Histolojik tiplere göre ayrıntılı yaş özellikleri (Tablo-1)'de verilmiştir.

Topografik dağılımları bilinen 4534 olgunun, \%52,5'i (n=2379) nodal, \%31'i $(n=1409)$ ekstranodal ve \%16,5'i $(n=746)$ kemik iliği (KI) yerleşiminden tanı aldı. Anatomik lokalizasyonlara göre ayrıntılı dağılım (Şekil-2)'de verilmiştir.

Olguların \%51,5'i $(n=1739)$ yaygın, \%37,8'i $(n=1275)$ lokalize ve \%7,9'u $(n=362)$ bölgesel hastalık oluşturmakta idi.

\section{Matür B ve T/NK Hücreli Neoplazmların Yıllara Göre Dağılım Özellikleri}

Olguların yıllara göre dağılımına baktığımızda, yarısından fazlasının 2009-2017 yılları arasında yer aldığı dikkatimizi çekti (Tablo-2). Yıllara göre cinsiyet dağılımı açısından anlamlı bir fark saptanmadı ( $p=0,613)$ (Tablo-2).

En çok hasta dağılımının izlendiği grupların, yıllara göre artış oranları değerlendirildi; matür Bhücreli neoplazmlar yıllara göre artış gösterirken, matür T-hücreli neoplazmlarda böyle bir artış saptanmadı. Sınıflandırılamayan NHL olgularının ise yıllara göre azaldığı dikkatimizi çekti. Histolojik tiplerin yıllara göre dağılımı istatistiksel olarak da anlamlı bulundu, ayrıntılı değerlendirilme (Şekil-3)'te verilmiştir $(p<0,0001)$.

Yıllara göre NHL'ların lokalize kalma oranlarının arttığı, bölgesel hastalık görülme oranlarının ise azaldığı dikkatimizi çekti. Yaygın hastalık oluşumu en çok 2000-2008 yılları arasında izlendi (Tablo-3). Yıllara göre hastalığın yaygınlığı istatistiksel olarak da anlamlı saptandı $(p<0,0001)$.

\section{Matür B ve T/NK Hücreli Neoplazmların Yaş Gruplarına Göre Dağılım Özellikleri}

Yaş dağılımlarına baktığımızda, olguların yaklaşık yarısı 40-64 yaş aralığında idi. Tüm yaş gruplarında erkeklerde kadınlara göre daha fazla ve istatistiksel olarak da anlamlı idi $(p=0,003)$ (Tablo-4). 


\section{Olguların histolojik tiplere göre dağılımı}

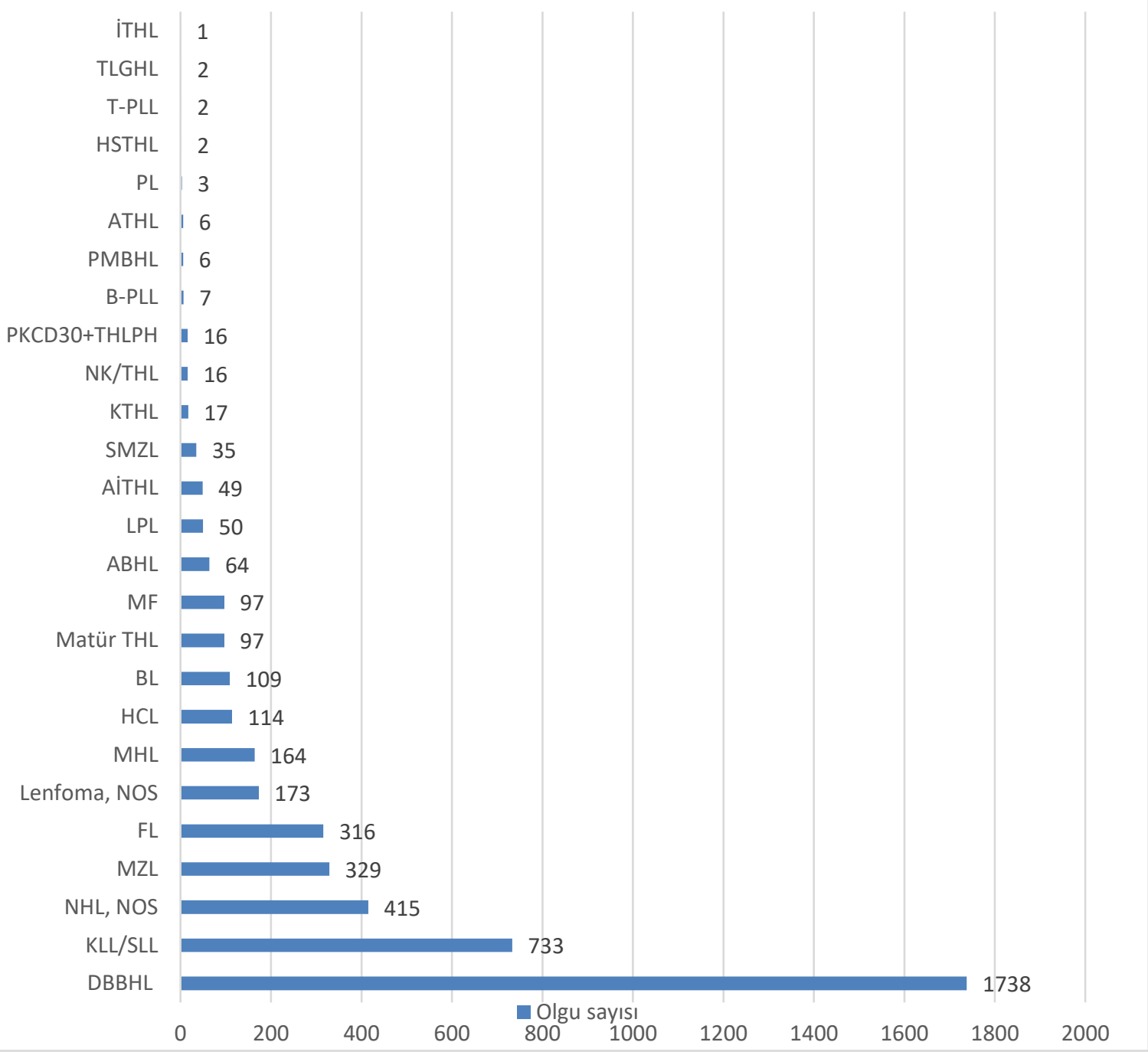

Şekil-1. Histolojik tiplere göre dağılım grafiği.

Kısaltmalar: DBBHL: Diffüz büyük B-hücreli lenfoma, KLL/SLL: Kronik lenfositik lösemi / küçük lenfositik lenfoma, NHL, NOS: Hodgkin dışı lenfoma, sınıflandırılamayan, MZL: Marjinal zon lenfoma, FL: Folliküler lenfoma, Lenfoma, NOS: Lenfoma, sınıflandırılamayan, MHL: Mantle hücreli lenfoma, HCL: Hairy cell lösemi, BL: Burkitt lenfoma, Matür THL: Matür T-hücreli lenfoma, MF: Mikozis fungoides, ABHL: Anaplastik büyük hücreli lenfoma, LPL: Lenfoplazmasitik lenfoma, AiTHL: Anjioimmunoblastik T-hücreli lenfoma, SMZL: Splenik marjinal zon lenfoma, KTHL: Kutanöz T-hücreli lenfoma, NKVTHL: NK/Thücreli lenfoma, PKCD30+THLPH: Primer kutanöz CD30-pozitif T-hücreli lenfoproliferatif hastalık, B-PLL: B-hücreli prolenfositik Iösemi, PMBHL: Primer mediastinal büyük B-hücreli lenfoma, ATHL: Adult T-hücreli lenfoma, PL: Plazmasitik lenfoma, HSTHL: Hepatosplenik T-hücreli lenfoma, T-PLL: T-hücreli prolenfositik lösemi, TLGHL: T-hücreli büyük granuler lenfositik lösemi, ITHL: Intestinal T-hücreli lenfoma. 
Tablo-1. Olguların histolojik tiplere göre yaş özellikleri.

\begin{tabular}{|c|c|c|c|c|}
\hline & Olgu sayısı & Ortalama yaş & Standart sapma & Aralık \\
\hline DBBHL & 1738 & 56,31 & 16,34 & $18-100$ \\
\hline KLL/SLL & 733 & 61,08 & 12,73 & $18-92$ \\
\hline NHL, NOS & 415 & 54,43 & 16,54 & $18-93$ \\
\hline MZL & 329 & 60,45 & 13,75 & $20-86$ \\
\hline $\mathrm{FL}$ & 316 & 55,20 & 14,05 & $19-89$ \\
\hline Lenfoma, NOS & 173 & 54,94 & 16,34 & $18-87$ \\
\hline MHL & 164 & 64,84 & 11,60 & $20-91$ \\
\hline $\mathrm{HCL}$ & 114 & 54,68 & 12,46 & $29-89$ \\
\hline $\mathrm{BL}$ & 109 & 44,21 & 16,96 & $18-84$ \\
\hline Matür THL & 97 & 50,53 & 15,47 & $19-78$ \\
\hline MF & 97 & 53,51 & 14,39 & $24-88$ \\
\hline $\mathrm{ABHL}$ & 64 & 46,25 & 15,93 & $18-76$ \\
\hline LPL & 50 & 63,98 & 13,24 & $23-88$ \\
\hline AITHL & 49 & 57,57 & 16,01 & $19-80$ \\
\hline SMZL & 35 & 58,51 & 12,89 & $32-85$ \\
\hline KTHL & 17 & 49,41 & 16,54 & $19-72$ \\
\hline NK/THL & 16 & 47,13 & 14,80 & $21-69$ \\
\hline PKCD30+THLPH & 16 & 52,19 & 13,42 & $29-75$ \\
\hline B-PLL & 7 & 68,71 & 15,37 & $35-80$ \\
\hline PMBHL & 6 & 42,33 & 15,73 & $28-66$ \\
\hline ATHL & 6 & 56,00 & 20,76 & $31-84$ \\
\hline PL & 3 & 65,67 & 8,96 & $60-76$ \\
\hline HSTHL & 2 & 38,00 & 9,89 & $31-45$ \\
\hline T-PLL & 2 & 63,00 & 1,41 & $62-64$ \\
\hline TLGHL & 2 & 57,00 & 28,28 & $37-77$ \\
\hline İTHL & 1 & 56,00 & - & - \\
\hline TOPLAM & 4561 & 56,77 & 15,60 & $18-100$ \\
\hline
\end{tabular}

Kısaltmalar: DBBHL: Diffüz büyük B-hücreli lenfoma, KLL/SLL: Kronik lenfositik lösemi / küçük lenfositik lenfoma, NHL, NOS: Hodgkin dışı lenfoma, sınıflandırılamayan, MZL: Marjinal zon lenfoma, FL: Folliküler lenfoma, Lenfoma, NOS: Lenfoma, sınıflandırılamayan, MHL: Mantle hücreli lenfoma, HCL: Hairy cell lösemi, BL: Burkitt lenfoma, Matür THL: Matür T-hücreli lenfoma, MF: Mikozis fungoides, ABHL: Anaplastik büyük hücreli lenfoma, LPL: Lenfoplazmasitik lenfoma, AiTHL: Anjioimmunoblastik T-hücreli lenfoma, SMZL: Splenik marjinal zon lenfoma, KTHL: Kutanöz T-hücreli lenfoma, NKJTHL: NK/Thücreli lenfoma, PKCD30+THLPH: Primer kutanöz CD30-pozitif T-hücreli lenfoproliferatif hastalık, B-PLL: B-hücreli prolenfositik lösemi, PMBHL: Primer mediastinal büyük B-hücreli lenfoma, ATHL: Adult T-hücreli lenfoma, PL: Plazmasitik lenfoma, HSTHL: Hepatosplenik T-hücreli lenfoma, T-PLL: T-hücreli prolenfositik lösemi, TLGHL: T-hücreli büyük granuler lenfositik lösemi, iTHL: Intestinal T-hücreli lenfoma. 


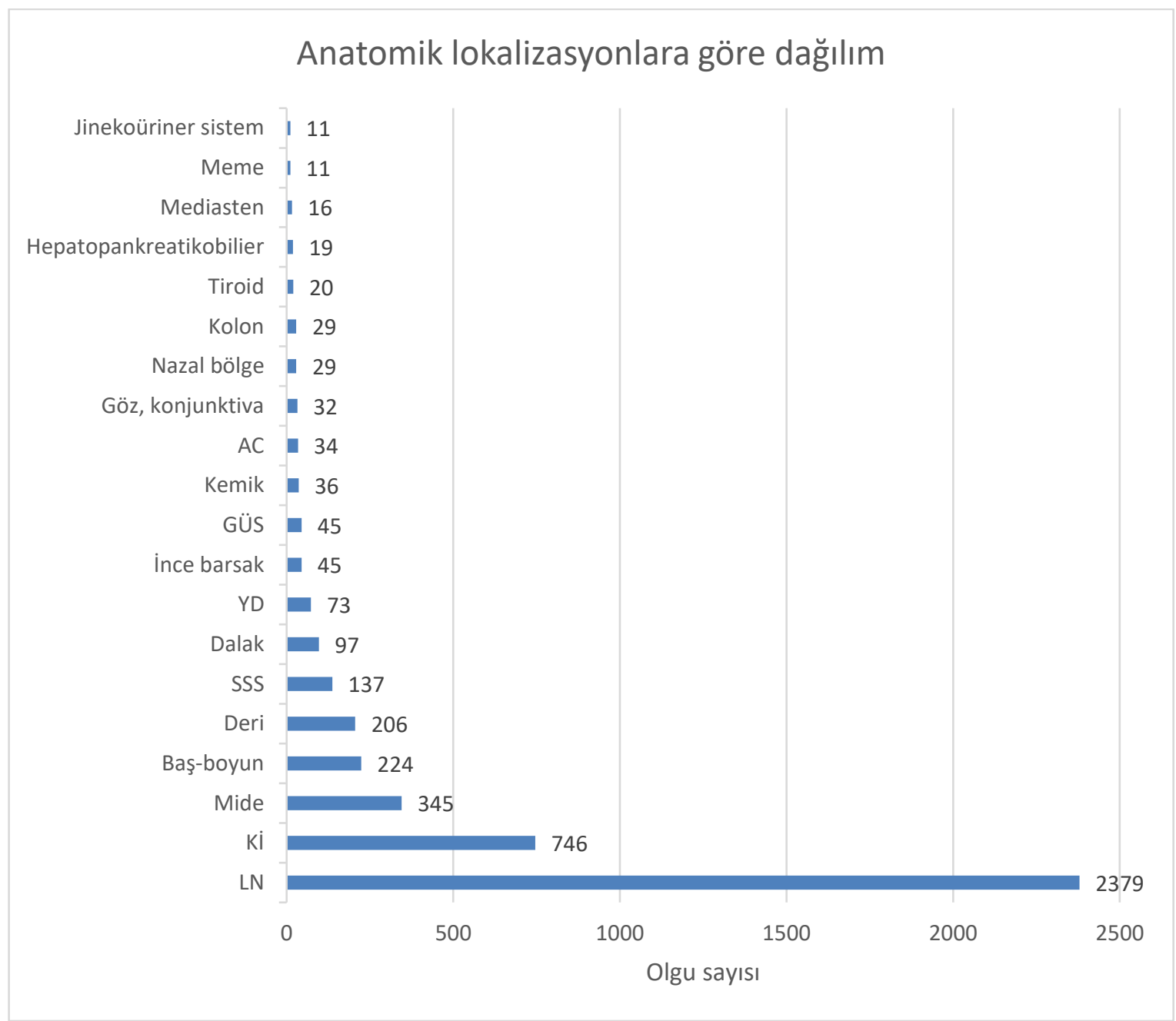

Şekil-2. Anatomik lokalizasyonlara göre dağılım grafiği.

Kısaltmalar: LN: Lenf nodülü, Ki: Kemik iliği, SSS: santral sinir sistemi, YD: Yumuşak doku, GÜS: Genitoüriner sistem, AC: Akciğer.

Tablo-2. Olguların yıllara göre dağılımları ve cinsiyet ilişkisi.

\begin{tabular}{lllll}
\hline & Olgu sayısı & Erkek & Kadın & p: 0,613 \\
\hline $1992-1999$ & $556(\% 13,6)$ & $325(\% 58,5)$ & $231(\% 41,5)$ & \\
$2000-2008$ & $1408(\% 34,5)$ & $790(\% 56,1)$ & $618(\% 43,9)$ & \\
$2009-2017$ & $2115(\% 51,9)$ & $1191(\% 56,3)$ & $924(\% 43,7)$ & \\
\hline
\end{tabular}




\section{Histolojik tiplerin yıllara göre dağı̆ımı}

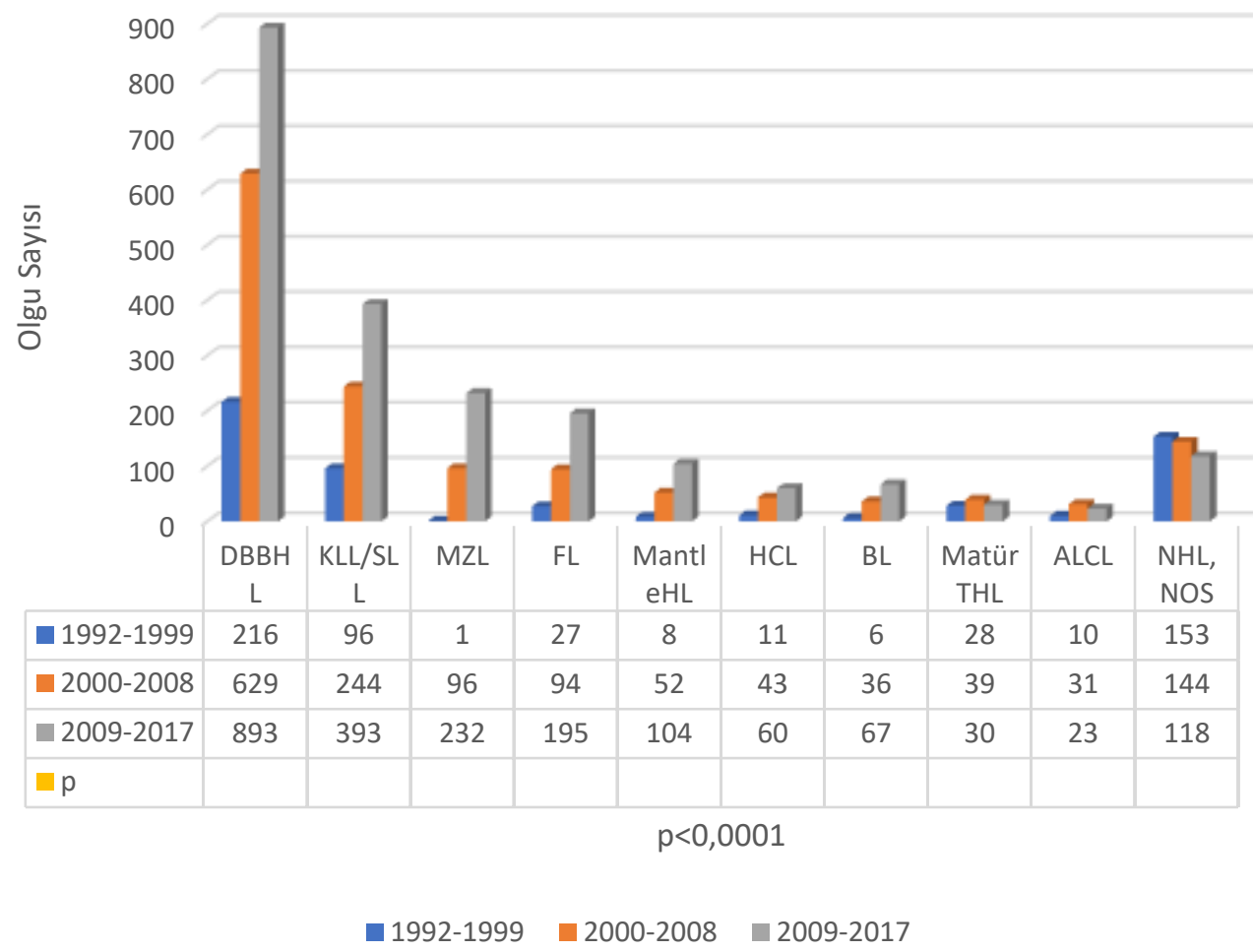

Şekil-3. Histolojik tiplerin yıllara göre dağılım grafiği.

Kısaltmalar: DBBHL: Diffüz büyük B-hücreli lenfoma, KLL/SLL: Kronik lenfositik lösemi / küçük lenfositik lenfoma, MZL: Marjinal zon lenfoma, FL: Folliküler lenfoma, MHL: Mantle hücreli lenfoma, HCL: Hairy cell lösemi, BL: Burkitt lenfoma, Matür THL: Matür T-hücreli lenfoma, ABHL: Anaplastik büyük hücreli lenfoma, NHL, NOS: Hodgkin dışı lenfoma, sınıflandırılamayan.

Tablo-3. Yıllara göre hastalığın yaygınlığı.

\begin{tabular}{lllll}
\hline & Lokalize & Bölgesel & Yaygın & P<0,0001 \\
\hline $1992-1999$ & $153(\% 32,7)$ & $83(\% 17,7)$ & $232(\% 49,57)$ & \\
$2000-2008$ & $296(\% 34,5)$ & $84(\% 9,7)$ & $479(\% 55,8)$ & \\
$2009-2017$ & $710(\% 40,5)$ & $160(\% 9,1)$ & $881(\% 50,3)$ & \\
\hline
\end{tabular}

Tablo-4. Yaş aralıklarına göre olguların dağı̆ımı.

\begin{tabular}{lllll}
\hline & Olgu sayısı & Erkek & Kadın & P=0,003 \\
\hline $18-39$ & $623(\% 15,3)$ & $370(\% 59,4)$ & $253(\% 40,6)$ & \\
$40-64$ & $2021(\% 49,5)$ & $1175(\% 58,1)$ & $846(\% 41,9)$ & \\
65 ve üstü & $1435(\% 35,2)$ & $761(\% 53)$ & $674(\% 47)$ & \\
\hline
\end{tabular}


Hastalık 18-39 yaş grubunda daha lokalize kalma eğiliminde iken, yaş arttıkça daha yaygın olarak izlendi ve aradaki fark istatistiksel olarak da anlamlı bulundu $(p<0,0001)($ Tablo-5).

En çok hasta dağılımının izlendiği grupların yaş aralıklarına göre dağılımı değerlendirildiğinde, $\mathrm{MHL}$ hariç diğer tiplerin en çok 40-64 yaş aralığında karşımıza çıktığı, MHL'nın ise en çok 65 yaş ve üstü grupta karşımıza çıktığı dikkatimizi çekti. Çocukluk yaş grubunda sık görülen BL'da ise olguların \%86,2'si 18-64 yaş aralığında idi. Histolojik tiplerin yaş aralıklarına göre dağılımı istatistiksel olarak da anlamlı saptandı $(p<0,0001)$.

Tablo-5. Yaş aralıklarına göre hastalığın yaygınlığı.

\begin{tabular}{lllll}
\hline & Lokalize & Bölgesel & Yaygın & P<0,0001 \\
$18-39$ & $202(\% 45,1)$ & $71(\% 15,8)$ & $175(\% 39,1)$ & \\
$40-64$ & $560(\% 36,7)$ & $157(\% 10,3)$ & $808(\% 53)$ & \\
65 ve üstü & $397(\% 35,9)$ & $99(\% 9)$ & $609(\% 55,1)$ \\
\hline
\end{tabular}

\section{Histolojik tiplerin yaş-aralıklarına göre dağılımı}

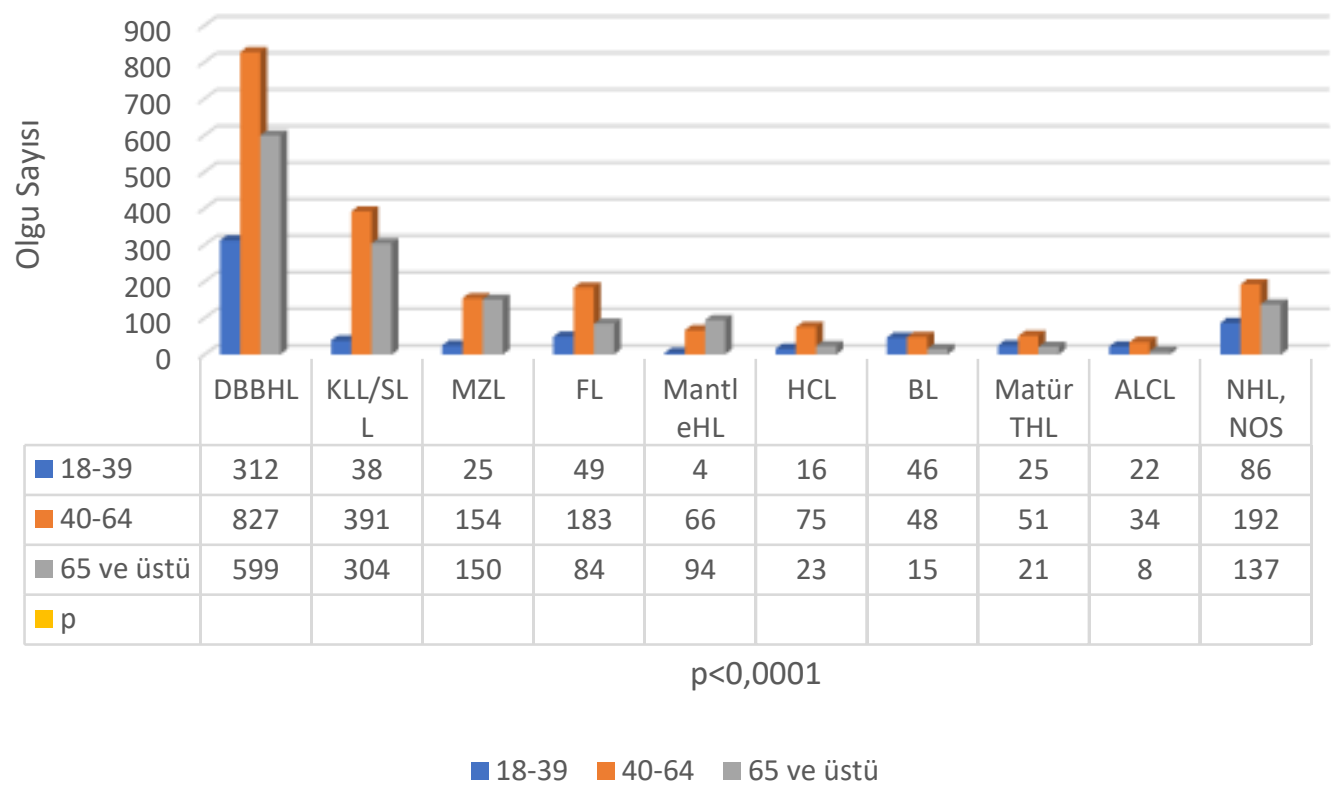

Şekil-4. Histolojik tiplerin yaş aralıklarına göre dağılım grafiği.

Kısaltmalar: DBBHL: Diffüz büyük B-hücreli lenfoma, KLL/SLL: Kronik lenfositik lösemi / küçük lenfositik lenfoma, MZL: Marjinal zon lenfoma, FL: Folliküler lenfoma, MHL: Mantle hücreli lenfoma, HCL: Hairy cell lösemi, BL: Burkitt lenfoma, Matür THL: Matür T-hücreli lenfoma, ABHL: Anaplastik büyük hücreli lenfoma, NHL, NOS: Hodgkin dışı lenfoma, sınıflandırılamayan.

Olguların ayrıntılı değerlendirilmesi Supplement -1 (Tablo-6)'da verilmiştir. 
Tablo-6. Olguların ayrıntılı dökümü.

\begin{tabular}{|c|c|c|c|c|c|c|c|c|c|c|c|c|c|c|c|c|c|c|c|c|c|c|c|c|}
\hline & $\begin{array}{l}\text { 퐁 } \\
\text { 品 } \\
\text { 口ิ }\end{array}$ & 岇 & $\stackrel{N}{\Sigma}$ & $\overrightarrow{4}$ & 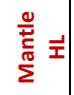 & 오 & $\vec{\omega}$ & 害 & $\stackrel{u}{\Sigma}$ & 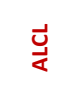 & $\vec{a}$ & 至 & $\sum_{n}^{N}$ & 至 & $\begin{array}{l}\stackrel{\overrightarrow{1}}{\mathbf{5}} \\
\frac{\hat{z}}{2}\end{array}$ & 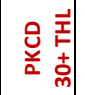 & 克 & $\begin{array}{l}\vec{I} \\
\sum_{0}^{0}\end{array}$ & 至 & $\vec{a}$ & 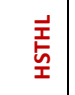 & 吉 & 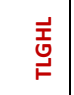 & 至 \\
\hline Erkek & 925 & 461 & 158 & 140 & 117 & 88 & 61 & 71 & 52 & 38 & 32 & 33 & 14 & 8 & 9 & 12 & 5 & 2 & 4 & 2 & 2 & 2 & 1 & 0 \\
\hline Kadın & 813 & 272 & 171 & 176 & 47 & 26 & 48 & 26 & 45 & 26 & 18 & 16 & 21 & 9 & 7 & 4 & 2 & 4 & 2 & 1 & 0 & 0 & 1 & 1 \\
\hline Toplam & 1738 & 733 & 329 & 316 & 164 & 114 & 109 & 97 & 97 & 64 & 50 & 49 & 35 & 17 & 16 & 16 & 7 & 6 & 6 & 3 & 2 & 2 & 2 & 1 \\
\hline Nodal & 1002 & 205 & 126 & 277 & 124 & 0 & 37 & 72 & 0 & 52 & 15 & 47 & 0 & 2 & 1 & 0 & 0 & 0 & 0 & 2 & 1 & 0 & 0 & 0 \\
\hline Ekstranodal & 717 & 14 & 190 & 37 & 35 & 0 & 29 & 25 & 97 & 12 & 4 & 2 & 35 & 15 & 12 & 16 & 0 & 6 & 0 & 1 & 1 & 0 & 0 & 1 \\
\hline Kemik iliği & 9 & 513 & 7 & 1 & 3 & 114 & 43 & 0 & 0 & 0 & 31 & 0 & 0 & 0 & 1 & 0 & 7 & 0 & 6 & 0 & 0 & 2 & 2 & 0 \\
\hline Baş-boyun & 138 & 2 & 33 & 7 & 12 & & 5 & 8 & & 1 & 1 & & & & 1 & & & & & & & & & \\
\hline Mide & 205 & 4 & 80 & 2 & 7 & & 6 & 1 & & 2 & 1 & & & & & & & & & & & & & \\
\hline İnce barsak & 26 & 1 & 5 & 0 & 2 & & 4 & 3 & & 0 & 0 & & & & & & & & & & & & & 1 \\
\hline Kolon & 14 & 0 & 2 & 2 & 2 & & 3 & 1 & & 0 & 0 & & & & & & & & & & & & & \\
\hline HPB & 16 & 1 & 1 & 0 & 0 & & 0 & 0 & & 0 & 0 & & & & & & & & & & & & & \\
\hline Nazal bölge & 11 & 0 & 0 & 0 & 1 & & 0 & 2 & & 0 & 0 & & & & 10 & & & & & & & & & \\
\hline Akciğer & 18 & 1 & 11 & 1 & 0 & & 0 & 0 & & 1 & 0 & & & & & & & & & & & & & \\
\hline Mediasten & 8 & 0 & 1 & 0 & 0 & & 0 & 0 & & 0 & 0 & & & & & & & 6 & & & & & & \\
\hline Kemik & 26 & 1 & 0 & 1 & 0 & & 0 & 0 & & 0 & 0 & & & & & & & & & & & & & \\
\hline Kemik iliği & 9 & 513 & 7 & 1 & 3 & 114 & 43 & 0 & & 0 & 31 & & & & 1 & & 7 & & 6 & & & 2 & 2 & \\
\hline Dalak & 24 & 1 & 25 & 1 & 3 & & 0 & 1 & & 0 & 0 & & 35 & & & & & & & & 1 & & & \\
\hline Deri & 33 & 0 & 7 & 14 & 0 & & 0 & 4 & 197 & 5 & 0 & & & 15 & 1 & 16 & & & & & & & & \\
\hline Yumuşak doku & 41 & 1 & 2 & 2 & 1 & & 3 & 3 & & 1 & 2 & & & & & & & & & & & & & \\
\hline Meme & 4 & 1 & 1 & 3 & 0 & & 0 & 0 & & 0 & 0 & & & & & & & & & & & & & \\
\hline Jinekoüriner & 9 & 0 & 0 & 0 & 0 & & 1 & 0 & & 0 & 0 & & & & & & & & & & & & & \\
\hline GÜS & 32 & 0 & 4 & 1 & 1 & & 2 & 1 & & 0 & 0 & & & & & & & & & 1 & & & & \\
\hline SSS & 95 & 1 & 3 & 1 & 1 & & 1 & 1 & & 2 & 0 & 2 & & & & & & & & & & & & \\
\hline Göz konjunktiva & 5 & 0 & 14 & 1 & 5 & & 1 & 0 & & 0 & 0 & & & & & & & & & & & & & \\
\hline Tiroid & 12 & 0 & 1 & 1 & 0 & & 3 & 0 & & 0 & 0 & & & & & & & & & & & & & \\
\hline Lenf nodülü & 1002 & 205 & 126 & 277 & 124 & & 37 & 72 & & 52 & 15 & 47 & & 2 & 1 & & & & & 2 & 1 & & & \\
\hline & $\begin{array}{l}\text { I } \\
\text { 䍛 }\end{array}$ & $\stackrel{n}{\vec{z}}=$ & $\stackrel{\vec{N}}{\Sigma}$ & 난 & 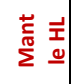 & 모 & $\vec{\infty}$ & 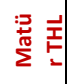 & $\stackrel{u}{\Sigma}$ & $\underset{d}{\vec{d}}$ & $\vec{a}$ & 夌 & $\sum_{n}^{N}$ & $\stackrel{\overrightarrow{\underline{I}}}{\underline{\underline{E}}}$ & 占立 & 总 & 吉 & $\sum_{0}^{\infty} \vec{x}$ & 夌 & $\vec{a}$ & 鸹 & 吉 & 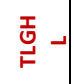 & 롵 \\
\hline Lokalize & 681 & 47 & 106 & 121 & 31 & 0 & 20 & 24 & 33 & 23 & 8 & 14 & 5 & 8 & 3 & 10 & 0 & 0 & 0 & 2 & 0 & 0 & 0 & \\
\hline Bölgesel & 192 & 14 & 21 & 21 & 11 & 0 & 10 & 10 & 5 & 8 & 0 & 4 & 2 & 1 & 2 & 2 & 0 & 3 & 0 & 0 & 0 & 0 & 0 & \\
\hline Yaygın & 373 & 595 & 120 & 90 & 80 & 103 & 58 & 33 & 10 & 13 & 38 & 16 & 19 & 2 & 5 & 1 & 7 & 0 & 5 & 1 & 2 & 2 & 2 & \\
\hline Toplam & 1246 & 656 & 247 & 232 & 122 & 103 & 88 & 67 & 48 & 44 & 46 & 34 & 26 & 11 & 10 & 13 & 7 & 3 & 5 & 3 & 2 & 2 & 2 & \\
\hline
\end{tabular}

Kısaltmalar: HPB: Hepatopankreatikobilier, GÜS: Genitoüriner sistem, DBBHL: Diffüz büyük B-hücreli lenfoma, KLL/SLL: Kronik lenfositik lösemi / küçük lenfositik lenfoma, NHL, NOS: Hodgkin dışı lenfoma, sınıflandırılamayan, MZL: Marjinal zon lenfoma, FL: Folliküler lenfoma, Lenfoma, NOS: Lenfoma, sınıflandırılamayan, MHL: Mantle hücreli lenfoma, HCL: Hairy cell lösemi, BL: Burkitt lenfoma, Matür THL: Matür T-hücreli lenfoma, MF: Mikozis fungoides, ABHL: Anaplastik büyük hücreli lenfoma, LPL: Lenfoplazmasitik lenfoma, AiTHL: Anjioimmunoblastik T-hücreli lenfoma, SMZL: Splenik marinal zon lenfoma, KTHL: Kutanöz T-hücreli lenfoma, NK/THL: NK/T-hücreli lenfoma, PKCD30+THLPH: Primer kutanöz CD30-pozitif T-hücreli lenfoproliferatif hastalık, B-PLL: B-hücreli prolenfositik lösemi, PMBHL: Primer mediastinal büyük B-hücreli lenfoma, ATHL: Adult T-hücreli lenfoma, PL: Plazmasitik lenfoma, HSTHL: Hepatosplenik T-hücreli lenfoma, T-PLL: T-hücreli prolenfositik Iösemi, TLGHL: T-hücreli büyük granuler lenfositik lösemi, ITHL: Intestinal T-hücreli lenfoma. 


\section{Tartışma}

NHL, gelişmiş ülkelerde en sık görülen hematolojik malignitedir (4). Bizim serimizde de en sık görülen hematolojik malignite NHL'dir ve Ienfoma tanısı alan olgularımızın yaklaşık \%79'unu oluşturmaktadır.

$\mathrm{NHL}$, yıllık insidansı birçok bölgede yıllar içinde artmaktadır (5). Birleşik Krallık'ta yaş standardize insidansı, 30 yılda (1988-2007) \%35 artmıştır (5). Benzer bir artış Amerika'da 1975-1991 yılları arasında yılda \%3,7 dolayında artarken, 19922007 yılları arasında ise yılda \%0,3'lük bir artış göstermektedir (5). Amerikan Kanser Derneği, 2011 yılında, 66.360 NHL tanısı alan yeni hasta ve 19.320 hastanın da bu hastalığa bağlı ölüm ile sonuçlandığını bildirmiştir $(2,6)$. Bizim serimizde de yılda 2000-2008 yılları arasında 2,24 ve 20092017 yılları arasında ise 3,38 oranında artış saptanmıştır. Lenfomaların yıllar içerisinde artış gösterdiği birçok çalışmada özellikle vurgulanmıştır (7). Çünkü Dünya'da artan yaşlı popülasyona paralel olarak, bu hastalık da son 20 yılda belirgin olarak artmıştır (6). Bizim olgularımızın \%51,9'u da 2009-2017 yılları arasında tanı almıştır. Gelişmiş ülkelerde daha sık görülen NHL, ABD'de 2014 yılında en sık görülen beşinci malignitedir $(3,5)$. Bizim serimizde de tüm malignitelerin \%4,1'ini oluşturmaktadır. GLOBOCAN 2018 verilerine göre insidansı erkeklerde \%3, kadınlarda \%2,6 dolayında saptanmıştır (8). Yaşlılarda DBBHL ve FL sırasıyla her yıl \%1,4 ve \%1,8 artarken, KLL/SLL \%2,1 azalmaktadır (9). Aynı çalışmada MZL, MHL ve BL'da da yıllar içerisinde artıştan söz edilmektedir (9). T-hücreli lenfomalar da yıllar içerisine artış görülürken, MF ise değişmeden kalmıştır (9). Bizim çalışmamızda da literatürle uyumlu olarak, B-hücreli lenfomalarda; DBBHL, KLL/SLL, MZL, FL, MHL, HCL ve BL'da yıllar içerisinde artış saptanmıştır. T-hücreli lenfomalarda (matür THL ve ALCL $A B H L$ ) ise literatürden farklı olarak böyle bir artış dikkati çekmemiştir. HCL ve FL beyazlarda daha sık görülürken, NK/T hücreli lenfomalar ve MF'in siyahlarda daha sık olduğu vurgulanmaktadır (9). $\mathrm{MHL}$ da beyaz-erkeklerde daha sık görülmektedir. Bizim ırkımızın daha çok beyaz olması ve viral etiyolojiye bağlı daha çok Uzak Doğu'da Karayip'lerde görülmesi T-hücreli lenfomalarda yıllara göre artışın olmamasının nedenlerinden biri olabilir (10). ABD'de 19922001 yılların arasında çok geniş bir seride yapılan çalışmada, histolojik tipi bilinmeyen lenfomaların yılda \%12 dolayında azaldığı görülmektedir (9). Bizim olgularımızda da sınıflandırılamayan NHL'ların yıllar içerisinde azalma oranı dikkat çekicidir (Şekil-3) $(p<0,0001)$. Bu durum yıllar içerisinde tanısal testlerin artması ve yaygınlaşması ile açıklanabilir.

NHL her yaşta karşımıza çıkabilmekle birlikte, genellikle ortalama 60 yaşta görülür $(6,11)$. Bazı çalışmalarda olguların üçte ikisi 60 yaş ve üzerinde bildirilmiştir (5). Bizim serimizde de ortalama tanı yaşı 56,77 , ortanca tanı yaşı 59 olarak bulunmuştur. Olgularımızın yaklaşık yarısı 40-64 yaş aralığında yer almaktadır. KLL/SLL ve FL'nın çocukluk yaş grubunda neredeyse karşımıza çıkması beklenmez (9). Çalışmamızda KLL/SLL'de ortalama tanı yaşı 61,08 (aralık:1892) olarak bulunmuştur. Ayrıca MHL hariç diğer NHL'lar en çok 40-64 yaş aralığında karşımıza çıkmıştır. Bu durum Türkiye nüfusunun daha genç popülasyona sahip olması ile ilişkili olabilir. BL'da ise 20-64 yaş grubunda, ileri yaşa göre daha fazla hasta bulunmaktadır (7). Literatüre benzer şekilde bizim serimizde de BL olgularının \%86,2'si 18-64 yaş aralığında yer almaktaydı. Histolojik tiplerin yaş aralıklarına göre dağılımı istatistiksel olarak da anlamlı saptandı $(p<0,0001)$. Çalışmalarda, PMBHL'da ise ortanca tanı yaşı $35(1,7), \quad F L$ ise 60 (5) olarak bildirilmiştir. Bizim olgularımızda PMBHL'da literatüre benzer şekilde ortanca tanı yaşı 35,5, FL'da ise 56 olarak bulundu. MHL'da ortanca tanı yaşı 58 olarak bildirilmiştir (5). Bizim serimizde de MHL en çok 65 yaş ve üstü grupta karşımıza çıkmıştır $(p<0,0001)$. PL'nin ortalama tanı yaşı ise 65,67 idi. Witte ve ark yaptığı çok merkezli çalışmada PL'da ortanca tanı yaşı 63 olarak bildirilmiştir (12). 
NHL gelişiminde immunsupresyon, çevresel etkenler yanı sıra enfeksiyöz etkenler de rol oynamaktadır $(1,7,11)$. BL gelişiminde Epstein Barr Virus (EBV), midede mukoza ilişkili lenfoid dokunun ekstranodal marjinal zon lenfoması (MALT lenfoma) gelişiminde Helicobacter Pylori ve primer effüzyon lenfoma gelişiminde ise Human Herpes Virus 8'in rol oynadığı gösterilmiştir. Buna bağlı olarak bazı NHL'ler geografik dağılım gösterir (5). HTLV1 enfeksiyonu ile ilişkili adult $T$ hücreli lenfoma ve EBV ile ilişkili NK/T hücreli lenfoma, nazal tip Doğu Asya'da diğer bölgelere göre daha sık görülürken, FL Batı Avrupa ve Kuzey Amerika'da daha yaygındır (5). Kanada'da yapılan bir çalışmada Çinli göçmenlerde $F L$ görülme oranının arttığı, NK/T HL görülme oranının ise azaldığını gösterilmiştir (13). Yani coğrafi ve ırksal faktörlerin hepsinin genetik olmadığı, çevresel faktörlerin de rol oynadığı düşünülebilir. Bizim ülkemizde DBBHL, FL'ya göre daha sık görülmektedir. BL için özellikle Afrika'da endemik olgular bildirilmekle birlikte sporadik olarak tüm dünya'da karşımıza çıkabilmektedir (5). Bizim olgularımızın da \%2,4'ünü BL oluşturmaktaydı.

B-hücreli lenfomalar $\% 85-90$ dolayında görülmektedir (5). Bizim serimizde olduğu gibi, Bhücreli lenfomalar, T-hücreli lenfomalara göre daha sık görülmekte olup; Morton ve ark yaptığı çalışmada, en sık DBBHL olmak üzere sırasıyla $\mathrm{KLL} / \mathrm{SLL}, \mathrm{FL}, \mathrm{MZL}$, mantle HL, Waldenström makroglobulinemisi, $\mathrm{HCL}$ ve $\mathrm{BL}$ görüldüğü bildirilmektedir (9). Bizim serimizde de en sık DBBHL olmak üzere, sırasıyla KLL/SLL, MZL, FL, MHL, HCL, BL dikkati çekti. Ayrıca DBBHL, NHL'lerin en sık görülen tipi olup, \%30-58'ini oluşturur $(3,5)$. Bizim serimizde $\% 37,9$ dolayında izlendi. Avrupa Ülkelerinde yılda 100.000 popülasyonda 3-4 yeni olgu bildirilmekte olup, yaşla birlikte artış göstermektedir (14). Literatürde FL, ikinci sıklıkta karşımıza çıkmakla birlikte, Batı toplumunda daha sık görülür (3). Yılda 100.000 popülasyonda 7 yeni olgu bildirilmektedir (14). ABD ve Batı Avrupa'da tüm $\mathrm{NHL}$ vakalarının yaklaşık \%20'sini oluşturmaktadır (5). ABD'ye göre Avrupa Ülkelerinde daha az görülmekle birlikte, Asya'da nadirdir (7). Bizim olgularımızın \%6,9'unu FL oluşturmaktadır. KLL/SLL ve MZL'dan sonra dördüncü sırada saptanmıştır. MZL, üçüncü sıklıkla karşımıza çıkan NHL tipidir (5). Bizim serimizde de üçüncü sırada olup, olguların $\% 7,2$ 'sini oluşturmaktadır. T-hücreli lenfomalar içinde PTHL en sık görülmekte olup, sırasıyla MF ve NK/T-hücreli lenfomalar olarak dağılım dikkati çekmektedir (9). Bizim serimizde de de en sık matür THL olmak üzere sırasıyla $M F, A B H L$, ALCL, AITHL, KTHL ve NK/THL olarak sıralanmaktadır.

Bazı çalışmalarda tüm NHL'ler içinde erkek:kadın oranı 1,5 ila 1,6 arasında değişmektedir (9). Bizim çalışmamızda da erkek:kadın oranı 1,3 dolayında olup, tüm yaş gruplarına baktığımızda erkeklerde kadınlara göre daha fazla ve istatistiksel olarak da anlamlı saptandı $(p=0,003)$. Literatürde $84.910 \quad$ B-hücreli NHL'nın değerlendirildiği çok geniş bir seride erkeklerde görülme oranı \%53,7 olarak bulunmuştur (16). Bizim serimizde de erkeklerde görülme oranı $\% 56,7$ 'dir. Özellikle BL ve HCL'de belirgin erkek üstünlüğü bildirilirken, $M Z L$ ve $F L$ 'da cinsiyet açısından belirgin farklar saptanmamıştır (9). Literatürle uyumlu olarak bizim serimizde de erkek: kadın oranı BL'da 1,3, HCL'de 3,4 olup, MZL'da 0,9 ve FL'da 0,8 olarak bulunmuştur. Folliküler lenfoma ve marjinal zon lenfoma dışında diğer lenfoma türleri erkeklerde kadınlardan daha sıktır (9). MHL'da bizim serimizde olduğu gibi 65 yaş üzeri erkeklerde artış göstermektedir (7). FL ve MZL'da ise kadın ve erkek oranı eşittir $(7,9)$. Sadece PMBHL'nın kadınlarda daha sık olduğu gösterilmiştir $(7,9)$. Bizim çalışmamızda da SMZL, KTHL ve PMBHL hariç, bütün histolojik tiplerde erkeklerde kadınlara göre daha sık olduğu saptandı. Thücreli lenfomalar için de özellikle sık görülen alt tiplerde, erkek: kadın oranı 1,8 ila 2 arasında değişmektedir (9). Bizim serimizde bu oran 1,7 olarak bulundu. Ayrıca başka bir çalışmada 7.662 T-hücreli lenfoma hastasının değerlendirildiği çok geniş bir seride erkeklerde görülme oranı $\% 58,9$ dolayında bulunmuştur (16). Bizim serimizde THL'ların erkeklerde görülme oranı \%62,8 dolayında saptanmıştır. AîTHL'da ise kadın erkek 
oranı eşit olarak bildirilmektedir (7). Bizim serimizde AiTHL'de, literatürden farklı olarak erkek:kadın oranı 2,06 olarak bulundu.

NHL'lar herhangi bir ekstranodal lokalizasyonda görülmekle birlikte, en sık mide başta olmak üzere Gis'de karşımıza çıkar (5). Bizim olgularımızın \%31'i de ekstranodal lokalizasyondan tanı aldı. Midede özellikle MALT lenfoma ve DBBHL görülür (5). Ekstranodal bölgeden tanı alan DBBHL olgularımızın çoğu GiS yerleşimli idi. MHL'da özellikle kolonda karşımıza çıkabilir (5). Gis'te lenfomatoid polipozise neden olabilir (5). Bizim serimizde MHL'nın en sık ekstranodal lokalizasyonu, başboyun ve Gis yerleşimiydi. Ayrıca literatürle uyumlu olarak bizim çalışmamızda da NK/THL'ların çoğu nazal bölge ve PMBHL olgularımızın tamamı da mediastenden tanı almıştır (1).

DLBCL DBBHL \%25 olguda lokalize kalabilmekle birlikte, genellikle yaygın hastalık şeklinde karşımıza çıkar (5). Bizim serimizde \%54,6 dolayında lokalize hastalık tablosu görülürken, $\% 29,9$ dolayında yaygın hastalık şeklinde karşımıza çıkmıştır. MHL'da genellikle yaygın hastalık tablosu oluşturur (5). Bizim serimizde de $\% 65,6$ yaygın hastalık tablosu ile karakterliydi. T hücreli lenfomalar içerisinde kutanöz $A B H L$ ve MF daha indolan seyir gösterirken, PTHL'lar agresif özellikler gösterir (5). Bizim serimizde de MF \%68,7, primer kutanöz THLPH ise $\% 75,9$ lokalize hastalık şeklinde karşımıza çıktı. Bilindiği gibi prognoz hastalığın histolojik tipi, evresi, yüksek LDH düzeyi, yaş ve risk faktörlerinin bulunmasına göre değişkenlik göstermektedir $(2,5)$. Çalışmamızda yıllara göre NHL'ların lokalize kalma oranlarının arttığı, bölgesel hastalık görülme oranlarının ise azaldığı dikkatimizi çekti. Yaygın hastalık oluşumu en çok
2000-2008 yılları arasında izlendi (Tablo-3). Yıllara göre hastalığın yaygınlığı istatistiksel olarak da anlamlı bulundu $(p<0,0001)$. Ayrıca hastalık 18-39 yaş grubunda daha lokalize kalma eğiliminde iken, yaş arttıkça daha yaygın olarak izlendi ve aradaki fark istatistiksel olarak da anlamlı bulundu $(p<0,0001)($ Tablo-5).

\section{Sonuç}

Sonuç olarak; FL, Batı Avrupa ve Kuzey Amerika'da daha sık görülürken, DBBHL Dünya'da daha yaygın görülmektedir. Bizim çalışmamızda da DBBHL en sık görülen NHL tipidir. FL ise Batı toplumları ile kıyaslandığında daha az karşımıza çıkmaktadır. Çalışmamızda NHL'ler erkeklerde kadınlara göre daha sık olup, aradaki fark istatistiksel olarak da anlamlı bulunmuştur. Ayrıca yıllara göre hastalığın lokalize kalma eğiliminin arttığı ve yaş gruplarına göre de 18-39 yaş aralığında daha lokalize kalma eğiliminde iken, yaş arttıkça daha yaygın hastalık tablosu oluşturduğu dikkatimizi çekmiştir. NHL'ye ait çok geniş bir serinin değerlendirildiği çalışmamız, ülkemize ait epidemiyolojik verilerin belirlenebilmesi açısından önem taşımaktadır. Sonuçlar ülkemizden bildirilen benzeri epidemiyolojik çalışmalarla desteklenerek, daha ayrıntılı ve kapsamlı veri analizleri ile birlikte değerlendirilmelidir.

Çıkar çatışması: Yazarlar çıkar çatışması beyan etmemişlerdir.

Teşekkür: Bu çalışma 25 yıllık uzun bir dönemi kapsamaktadır. Bu süreçte emekleri geçen tüm Ege Üniversitesi Hematoloji Bilim Dalı öğretim üyeleri ve olguların tanı sürecinde eğitimimize sonsuz katkılarından dolayı hocamız Prof. Dr. Saliha Soydan'a, EÜKAM yetkilisi Ömer Karaca başta olmak üzere tüm kanser kayıt elemanlarına teşekkür ederiz. 


\section{Kaynaklar}

1. Swerdlow SH, Campo E, Harris NL, et al. WHO classification of tumours of haematopoietic and lymphoid tissues, 4th edition (IARC WHO Classification of Tumours, Volume 2). International agency for research on Cancer (IARC). Lyon, 2017:215-421.

2. Guerard EJ, Bishop MR. Overview of Non-Hodgkin's Lymphoma. Dis Mon 2012;58(4):208-18.

3. Li Y, Wang Y, Wang Z, Yi D, Ma S. Racial Differences in Three Major NHL Subtypes: Descriptive Epidemiology. Cancer Epidemiol 2016;39(1):8-13.

4. Pulte D, Jansen L, Gondos A, et al. Survival of patients with non-Hodgkin lymphoma in Germany in the early 21st century. Leuk Lymphoma 2013;54(5):979-85.

5. Shankland KR, Armitage JO, Hancock BW, Park W. Non-Hodgkin lymphoma. Lancet 2012;380(9844):84857.

6. Siegel R, Ward E, Brawley O, Jemal A. Cancer Statistics, 2011: The Impact of Eliminating Socioeconomic and Racial Disparities on Premature Cancer Deaths. CA Cancer J Clin 2011;61(4):212-36.

7. Skrabek P, Turner D, Seftel M. Epidemiology of Non-Hodgkin Lymphoma. Transfus Apher Sci 2013;49(2):133-8.

8. Bray F, Ferlay J, Soerjomataram I, Siegel R, Torre LA, Jemal A. Global Cancer Statistics 2018: GLOBOCAN Estimates of Incidence and Mortality Worldwide for 36 Cancers in 185 Countries. CA Cancer J Clin 2018;68(6):394-424.

9. Morton LM, Wang SS, Devesa SS, Hartge P, Weisenburger DD, Linet M. Lymphoma incidence patterns by WHO subtype in the United States, 1992-2001. Blood. 2006;107(1):265-76.

10. Zell M, Assal A, Derman O, Kornblum N, et al. Adult T-cell leukemia/lymphoma in the Caribbean cohort is a distinct clinical entity with dismal response to conventional chemotherapy. Oncotarget 2016;7(32): 51981-90.

11. Czarnota J, Gennings C, Colt JS, et al. Analysis of Environmental Chemical Mixtures and Non-Hodgkin Lymphoma Risk in the NCI-SEER NHL Study. Environ Health Perspect 2015;123(10):965-70.

12. Witte HM, Hertel $\mathrm{N}$, Merz $\mathrm{H}$, et al. Clinicopathological characteristics and MYC status determine treatment outcome in plasmablastic lymphoma: a multi-center study of 76 consecutive patients. Blood Cancer $\mathrm{J}$ 2020;10(5):63.

13. Au WY, Gascoyne RD, Klasa RD, et al. Incidence and spectrum of non-Hodgkin lymphoma in Chinese migrants to British Columbia. Br J Haematol 2005;128(6):792-6.

14. Morgan $G$, Vornanen $M$, Puitinen J, et al. Changing trends in the incidence of non-Hodgkin's lymphoma in Europe. Biomed Study Group. Ann Oncol 1997;8(Suppl 2):49-54.

15. Mounier M, Bossard N, Remontet $L$, et al. Changes in dynamics of excess mortality rates and net survival after diagnosis of follicular lymphoma or diffuse large B-cell lymphoma: comparison between European population-based data (EUROCARE-5). Lancet Haematol 2015;2(11):e481-91.

16. Crozier JA, Sher T, Yang D, et al. Persistent Disparities Among Patients With T-Cell Non-Hodgkin Lymphomas and B-Cell Diffuse Large Cell Lymphomas Over 40 Years: A SEER Database Review. Clin Lymphoma, Myeloma Leuk 2015;15(10):578-85. 